\title{
Crafting a Confucian Culture in Chinese Corporations: A Case Study of Guangzhou Borche
}

\begin{abstract}
By Saiyu $\mathrm{Gu}^{*}$ and Haowen $\mathrm{Liu}^{ \pm}$
Corporate culture is an important source of enterprise's soft power. Confucianism, which has been regarded as official teaching over a thousand years, manifests its profound values in modern management and is adopted by a number of private companies in China. This paper employs a case study method, concentrating on the development of Borche - a private enterprise in Guangzhou. Data and other information were collected from interviews, open reports and historical records and got ensured by triangulation verification. It seeks to explain how the Confucianism got internalized as part of a corporate culture and serves us its management guideline. The result demonstrates that the internalization of Confucian values in a corporation will go through three stages: cultural identity, identity strengthening and spontaneous order. Confucianism's corporate culture is reflected in four aspects: of spirit, institution, behavior, and matter. The cultural infiltration mechanism is thus created.
\end{abstract}

Keywords: corporate culture, Confucianism, cultural internalization mechanism, culture evolution

\section{Introduction}

Corporate culture is deeply rooted in its social context thus traditional belief is, in fact, the cornerstone for most companies. For example, the culture of Western companies has long been influenced by religious elements such as the Christian teaching. While encouraging freedom, independence and innovation, they are also constrained by values including integrity, honesty and equality. Although Chinese enterprises are now open to the ideas of modern management, there is no comparable attempt of incorporating its traditions into organizational culture. Many companies now turn to Confucian, Buddhism and Taoism whilst the culture construction is still influenced by path dependence that makes the process superficial and even deviates from the core traditional values.

Scholars are increasingly advocating building corporate cultures with Chinese cultural characteristics. However, most of the existing researches focus on describing the factors that influence corporate culture, and less on the dynamic process of cultural internalization. To explore the evolution and internalization of Confucian values in a corporation, this research employs the case study method, taking a medium-sized private enterprise -Guangzhou Borche- as a subject and builds a three-stage corporate cultural evolution model and explores the cultural evolution process.

\footnotetext{
*Postgraduate Student, Shanghai International Studies University, China.

${ }^{ \pm}$Postgraduate Student, Shanghai International Studies University, China.
} 


\section{Literature Review}

\section{Corporate Culture Construction and Evolution Mechanism}

Conbere and Heorhiadi (2006) proposed the general evolution path. He believes that organizational culture is composed of four layers of intersecting and independent systems, ideas, personality, and background. These four factors interact and accelerate the development of organizational culture. His research recognizes the corporate culture as a dynamic process for the first time. Hofstede et al. (1990) attributes the evolution of corporate culture to values, rituals, heroes, and symbols. This theory describes cultural evolution as an "Onion Model" which successfully explained multiple cases of corporate culture establishment. Ellinas et al. (2017) introduces an empirically-grounded, agent-based model which relaxes a set of assumptions that describes past work -(a) omittance of an individual's strive for achieving cognitive coherence (b) limited integration of important contextual factors- by utilizing networks of beliefs and incorporating social rank into the dynamics.

This article mainly agrees with Sackmann (1997) that corporate culture is a complex, spontaneous and changing system. This system manifests itself as a self-organizing process in enterprises. The transformation of corporate culture is realized through the internal and external information. At the same time, the organizational culture has different characteristics at each stage within its life cycle (Cheng 2007), information flows through the change of different stage.

Chinese scholars also have some conspicuous findings on the evolution path of corporate culture. Xin and Xu (2004) use an existing scaling system and questionnaires and organize group discussions to study the structure of Chinese state-owned enterprise (SOE) culture. They have identified ten dimensions of SOE culture. Moreover, Wang (2015) chooses the four most representative enterprise culture construction cases from 50 candidate enterprises and conducts the research by using the method of business anthropology. He constructs theory model on the basis of analyzing the first hand data collected using NVio.10 and ATLAS.TI two qualitative analysis software.

\section{Confucian Values and Corporate Culture}

Confucian ethics is basically humanistic, obligation, and collectivistic in nature (Ip 2009). Confucianism believes that people are supposed to be selfmotivated through morality. In the enterprise management, the oriental values emphasize achieving management goals through moral construction instead of mandatory regulation (Nadkarni and Barr 2008). Chinese enterprises mainly concentrate on the core elements of Confucianism and leave out secondary qualities or peripheral features. In Japan, companies absorbed the Confucian "harmony" culture and created a "lifetime employment system". In Korea, companies advocate "diligence" so that employees are dutiful in their 
work. Hofstede and Bond (1988) added a fifth dimension to the original four dimensions of national cultural characteristics: Confucian dynamics. East and Southeast Asian countries score higher on the fifth dimension, which explains the relationship between cultural characteristics and business development.

In conclusion, Chines scholars' research on Confucian culture and corporate culture mostly focuses on the mutual influence factors and common characteristics of the two, and less on the role of culture in enterprises; while western scholars' research on Confucian culture is mainly carried out from the social level, rarely involving individual units and separating from the corporate characteristics of China. Therefore, this article attempts to explore the evolutionary path of corporate culture by combining the evolution of corporate culture with the development cycle of the enterprise. At the same time, it explores case studies and researches on local private enterprise management innovation practices with Confucian culture as the main corporate culture.

\section{Methodology}

\section{Sample Selection}

As a qualitative research, this paper selects Borche as our sample and the research design is in line with the principle of typicality and reproducibility (Eisenhardt and Graebner 2007).

Firstly, Guangzhou Borche Machinery Co., Ltd. is a tech firm focusing on high-precise and eco-friendly molding machines. Since it established, Borche has been continuously explored innovative management methods and introduced traditional culture to provide guidance for development at its early stage. Borche is a typical case that realized the merge of Confucianism culture and modern management. Next, Borche's development is accompanied by the Chinese economic reform. Its export business enables Borche to get exposed to the global market as well as the management skills, insights, and cultures in western corporations. It is a very typical sample for most medium-sized companies in Guangzhou province where private enterprises take a large proportion in the local economy and high-tech enterprises are concentrated. Therefore, the case study is representative and repeatable in an academic sense.

\section{Data Sources}

The data derives from interviews and secondary sources. In August 2018, we interviewed the chairman, high-level managers, and general associates. Interviews were conducted in group chat and dialogue interviews (one-on-one), and the information is recorded and reorganized into texts. Table 1 summarizes the data collection. 
Table 1. Data Sources

\begin{tabular}{|l|l|}
\hline Data type & \multicolumn{1}{|c|}{ Source } \\
\hline \multirow{5}{*}{ Interviews } & $\begin{array}{l}\text { Interview time: 2018.8.17 } \\
\text { 1. Chairman of Borche: 1 hour and 45 minutes }\end{array}$ \\
& $\begin{array}{l}\text { 2. Chairman, sales manager, technology manager, etc. (six } \\
\text { informants): 1 hour 9 minutes and 27 seconds }\end{array}$ \\
& $\begin{array}{l}\text { 3. Senior manager of operation department: 10 min 44 seconds } \\
\text { (more than 30,000 words) }\end{array}$ \\
\hline \multirow{5}{*}{ Secondary data } & $\begin{array}{l}\text { 1. Official website of Borche } \\
\text { 2. Newspaper }\end{array}$ \\
& $\begin{array}{l}\text { 3. Official accounts of Borche on Wechat } \\
\text { (more than 70,000 words) }\end{array}$ \\
\hline
\end{tabular}

\section{Results}

\section{The Cultural Internalization Mechanism}

This article applies the inductive method and divides the evolutionary process of Confucianism within a corporation into three stages: cultural identity, identity strengthening, and spontaneous order. To verify the influence of Confucianism on corporate management and test the validity of the qualitative research, this article uses trigonometric verification (Yin 2013) that introduces three sources of evidence: factual evidence (events in corporate culture construction practice), textual evidence (official data) and verbal evidence (from interviews). We use Nvivo 11 to encode and analyze these evidences and exhibit the internalization mechanism of Confucianism at each stage.

\section{Cultural Identity}

It is normal that employees and leaders to have distinct views. So exploring cultural consistency is imperative for Chinese enterprises. Confucian culture is deeply rooted in Chinese society. It plays a role in evaluating and regulating external behavior (Cheng 2014). People have been exposed to Confucian ethical teachings (e.g., filial piety, integrity and gratitude) for a long time. Borche has selected traditional principles that fit for its real situation to build its corporate culture and has also referred to Inamori Kazuo's management philosophy.

Confucianism is a humanistic philosophy that could complement the scientific management theory. Its implications for business management are: people-centered moral-oriented and behaving oneself to manage others (Liu 2006). As for Borche, in its early stages of cultural construction, there was a set mechanism for the management and employees to interact effectively. Cultural identity was reflected in both psychological and behavioral respects: for one, according to Confucian humanism, Borche began to attach importance to employees' thoughts and improve employees' occupation accomplishment. The evidence such as A1 and B1 in Table 2 shows that Borche tries to arouse 
the employees' conscience, integrity, filial piety and so forth. For another, only with the help of sincerity, one would be able to rectify one's heart (zheng xin), and only this way man would be able to practice self-cultivation (xiu shen). Once cultivated, the own family was brought to unison (jia qi), and only with families in unison a state could be governed (zhi guo) in the right way. If all this were achieved, there would be a harmony human relationship in the world (tianxia ping). Pieces of evidence such as A2 and B2 show that employees will take the initiative to receive cultural education. Above all, this paper proposes the proposition I:

Proposition I: In the first stage, employees and the company work together as a community of common interests. The company introduces Confucian culture to stimulate employees' cultural identity (sincerity), and employees who have a sense of self-cultivation link their development goals with the enterprise's goals, and the two sides then develop into a community of common goals.

Table 2. Evidence of Cultural Identity Stage

\begin{tabular}{|c|c|c|}
\hline Stage & Evidence & Classification \\
\hline \multirow{3}{*}{$\begin{array}{l}\text { Cultural } \\
\text { Identity }\end{array}$} & $\begin{array}{l}\text { Factual evidence (A): } \\
\text { A1: The chairman and other senior managers are } \\
\text { adhering to the traditional values and have joined a } \\
\text { Confucianism community in Beijing. } \\
\text { A2: The company has organized a cultural training } \\
\text { program to make junior employees recognize the } \\
\text { enterprise value and improve their works. }\end{array}$ & \multirow{3}{*}{$\begin{array}{l}\text { 1)Rectify one's heart } \\
\& \text { accomplish } \\
\text { sincerity } \\
\text { (A1, B1, B3, C1) } \\
\text { 2)Practice self- } \\
\text { cultivation \& bring } \\
\text { family in unison } \\
\text { (A2, B2, B4, C2) } \\
\text { Community of } \\
\text { common interests -- } \\
\text { Community of } \\
\text { common goals }\end{array}$} \\
\hline & $\begin{array}{l}\text { Textual evidence (B): } \\
\text { B1: "Just entered Bo Chuang, I received cultural } \\
\text { education". } \\
\text { B2: "Since the company has promoted the study of } \\
\text { traditional culture, many employees regard Disciple } \\
\text { Regulation as a mirror and constantly regulate their } \\
\text { own words and deeds". } \\
\text { B3: "Principles of heaven and conscience are the } \\
\text { same in essence". } \\
\text { B4: vPut down the ego and think for others". }\end{array}$ & \\
\hline & $\begin{array}{l}\text { Verbal evidence (C): } \\
\text { C1: "What is known without thinking is the innate } \\
\text { knowledge of goodness". } \\
\text { C2: "There is no one outside the ethical relationship". }\end{array}$ & \\
\hline
\end{tabular}

Source: field interview, August 2018.

\section{Identity Strengthening}

In order to develop continuously, enterprises will take further measures to transform employees' cultural identity into a substantial and practical system. In this way, enterprises could utilize soft power to affect an employee's performance. Confucianism believes that everyone has an inner conscience and can be stimulated to contribute to social goods. Yet it also admits that everyone has shortcomings. The modern business management functions as a supplementary part of moral 
governance. The evidence such as B5 and B8 in Table 3 show that Borche manages to optimize resource allocation, coordinate their own interests and supervise employees' behaviors to satisfy the Confucian value in a material aspect. At the same time, Confucianism values human agency and believes that the evil thought could be purified and follow the virtues after education. With moral education in enterprise management, employees will "make products with conscience and services with sincerity and love" (evidence B6 and C3). At this stage, the enterprise continuously strengthens the ideas of benevolence, goodwill and altruism. Employees accept these ideas and apply them to their work that reflects in the improvement of production and business operation. Both employees and employers are interconnected and prosperous. Now we have the second proposition:

Proposition II: In the second stage of cultural infiltration, enterprises strengthen cultural construction through external intervention (learning for practice), employees take the initiative to improve their work (goodwill and altruism); they now become a community of shared future.

Table 3. Evidence of Identity Strengthening Stage

\begin{tabular}{|c|c|c|}
\hline Stage & Evidence & Classification \\
\hline \multirow{3}{*}{$\begin{array}{l}\text { Identity } \\
\text { Strengthening }\end{array}$} & $\begin{array}{l}\text { Factual evidence (A): } \\
\text { A3: Borche set up classes to learn the idea of "attaining } \\
\text { liangzhi" and has daily departmental meetings to learn } \\
\text { traditional culture. } \\
\begin{array}{l}\text { A4: What man knew by instinct was liangzhi } \\
\text { (knowledge of goodness). }\end{array}\end{array}$ & \multirow{3}{*}{$\begin{array}{l}\text { (3)learning for } \\
\text { practice } \\
\text { (A3, B5, B7, } \\
\text { B8) } \\
\text { (4)goodwill and } \\
\text { altruism } \\
\text { (A4, B6, C3, } \\
\text { C4) } \\
\text { community of } \\
\text { common goals - } \\
\text { community of } \\
\text { shared future }\end{array}$} \\
\hline & $\begin{array}{l}\text { Textual evidence (B): } \\
\text { B5: "The company tries its best to gather all resources } \\
\text { and take all the staff into consideration". } \\
\text { B6: "The meaning of work is to bring products to life". } \\
\text { B7: Borche is not only a manufacturing plant for } \\
\text { injection molding machines, but also a training school } \\
\text { for shaping healthy personality". } \\
\text { B8: "Leaders themselves should adhere to the } \\
\text { traditional culture, but also guide, motivate and drive } \\
\text { each member of the team to achieve the goal } \\
\text { effectively". }\end{array}$ & \\
\hline & $\begin{array}{l}\text { Verbal evidence (C): } \\
\text { C3: "Be kind to others is the basic requirement for } \\
\text { service personal". } \\
\text { C4: "Life will be happier by incorporating refined } \\
\text { ideas into life and work". }\end{array}$ & \\
\hline
\end{tabular}

Source: field interview, August 2018. 


\section{Spontaneous Order}

Confucianism also involved discussion of human nature and people could be easily influenced by the environment. The management thought embodied in Confucian culture is the most abundant about human nature. Mencius's "the Goodness of Human Nature" is similar to the "Theory Y" in modern management. They all admit that the nature of human nature is pure and good, and the highest realm of management is that the driving force of business development comes from people's value pursuits. In other words, employees conceive the enterprise's mission as their own task.

For both company and employees, sticking to the "baopu" and "shouzhuo" spirits is to correct the existing drawbacks (evidence A5, evidence B9) and remain true to their original aspirations (evidence C6) in Table 4, and this culture further prompts innovation and improvement. This internal driving force will bring employees a sense of mission that connecting their individual interests with the collective goals. It makes employees firmly believe in the corporate culture and fully integrate themselves into the enterprise. Now we could draw the third proposition:

Proposition III: In the stage of spontaneous operation of culture, the company returns to the original aspiration of the enterprise (embrace simplicity), and hopes that employees can also reflect on themselves (nurture his nature), and the employees and the corporation become a community of shared mission.

Table 4. Evidence of Spontaneous Order Stage

\begin{tabular}{|c|c|c|}
\hline Stage & Evidence & Classification \\
\hline \multirow[b]{2}{*}{$\begin{array}{l}\text { Spontaneous } \\
\text { Order }\end{array}$} & $\begin{array}{l}\text { Factual evidence (A): } \\
\text { A5: The company adjusts the development thought, } \\
\text { improves the management strategy, advocates to do } \\
\text { the subtraction. }\end{array}$ & \multirow[b]{2}{*}{$\begin{array}{l}\text { (5)sticking to the } \\
\text { original aspiration } \\
\text { (A5, B9, C5, C6) } \\
\text { (6)remains pure } \\
\text { (B10, B11, B12, } \\
\text { C7) } \\
\text { community of } \\
\text { shared future - } \\
\text { community of } \\
\text { shared mission }\end{array}$} \\
\hline & $\begin{array}{l}\text { Textual evidence (B): } \\
\text { B9: "Borche needs to focus one thing and do it well" } \\
\text { B10: "Be humble is important for Borche: do } \\
\text { everything right and make every good machine". } \\
\text { B11: "Those in power should not try to influence } \\
\text { people or things with ideas or demands that run } \\
\text { counter to their natural conditions. Instead, they } \\
\text { should guide the populace back to its simple, natural } \\
\text { origin". } \\
\text { B12: "In this industry, be humble means craftsman } \\
\text { spirit and we should spare no effort to make perfect } \\
\text { machines". }\end{array}$ & \\
\hline
\end{tabular}




\begin{tabular}{|l|l|l|}
\hline & Verbal evidence (C): \\
C5: "Since established, we were determined to make \\
the best injection modeling machine". \\
C6: "Many problems need to be traced back to their \\
roots". \\
$\begin{array}{l}\text { C7: "Every product we produced is like our own } \\
\text { children and we should be responsible for every } \\
\text { product". }\end{array}$
\end{tabular}

Source: field interview, August 2018.

\section{Mechanism Construction}

As the development of enterprises has its own life cycle, the corporate culture has corresponding characteristics at each stage. The influence of corporate culture on individuals is dynamic. We conduct the inductive reasoning in a hierarchical way to analyses the association among variables in the process of cultural internalization. Therefore, this paper divides the merge of Confucian values in corporate culture into three parts: cultural identity, identity strengthening, and spontaneous order according to the degree of employees' cognition and the change of their attitudes (from passive acceptance at the beginning to the exertion of their subjective initiative) in the process of cultural construction. At each stage, enterprises selectively introduce the management elements from Confucian culture, adjust strategies and improve their systems and regulation. In the cultural evolution, the relationship between employees and enterprises becomes closer as the corporate culture deepens. To sum up, the cultural construction mechanism is shown in Figure 1.

In the beginning, the introduction of Confucian culture is to raise the employees' attention to their own quality and help them to set goals. Then in the second stage, the enterprise emphasizes integrity, conscience, and goodwill to reshape employees' values and encourages them to play these qualities. Lastly, facing the development dilemma, enterprises and employees choose to return to their original aspiration, take a retreat as a step forward, and seek a breakthrough from their own characteristics to achieve management innovation. It is worth noting that in this process, culture internalization and individual response fit and interact with each other. The more culture fits with the individual, the more independent and socialized individuals will be after infected by culture, and it is easy to make better performance. After getting external positive feedback, individuals open their minds, actively respond to the new culture or participated in crafting the new corporate culture. 
Figure 1. Corporate Cultural Internalization Mechanism

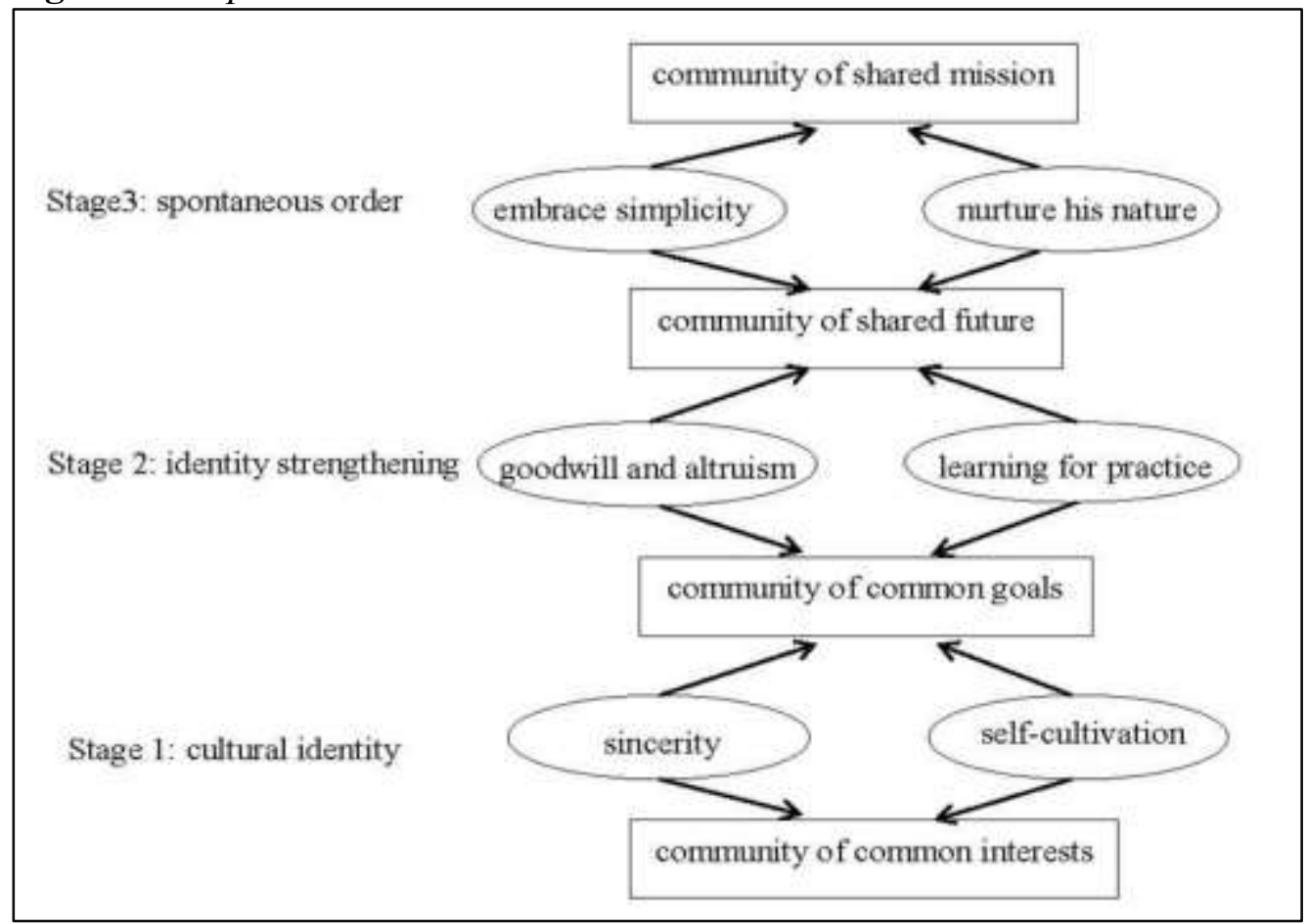

Source: author 2019.

\section{Cultural Evolution Analysis}

If the enterprise is a living organism, the enterprise culture is periodic. Taking the life cycle of enterprise development as the time axis and the cultural evolution as the background, this paper divides the evolution process of Bo Chuang culture into three stages: culture exploration stage, culture introduction stage and culture development stage. Combined with the four levels of cultural structure: spirit, institution, behavior and materials (Liu 2006), this paper analyzes the evolution of Confucian culture from multiple perspectives.

Culture Exploration Stage (2002-2011)

In 2002, the founder of Borche resigned from the position of domestic general manager with an annual salary of million yuan because he was not satisfied with the value of "benefit first" in his company. He is convinced that shareholders, customers, and employees are integrated, so he puts forward the enterprise tenet of "broad and profound, value co-production". Since China strongly advocated the construction of traditional culture, there is an upsurge of learning Sinology all over the country. The founder of Borche learned the management concept of Kazuo Inamori by chance and was deeply inspired. Inamori's management concept is a combination of Chinese Confucian culture and enterprise management. While the philosophical foundation of Inamori and the philosophical basis of the Meiji Restoration in Japan, are the ideas of "attaining liangzhi" which was raised by the Ming-dynasty philosopher Wang Shouren. In order to implement the idea of "respect for nature and love for mankind" and the idea of "life is everything", 
Borche began to vigorously promote Confucian culture within the enterprise. Since the company is still in the early stage of culture construction, it faced many management defects at the spiritual level, institutional level, behavioral level and matter level. Evidence examples are shown in Table 5.

Table 5. Evidence in Culture Exploration Stage

\begin{tabular}{|c|c|c|}
\hline Stage & Evidence & Classification \\
\hline \multirow{3}{*}{$\begin{array}{l}\text { Culture } \\
\text { Exploration } \\
\text { (2002-2011) }\end{array}$} & $\begin{array}{l}\text { Factual evidence (A): } \\
\text { A1: The brother culture in the early days of } \\
\text { entrepreneurship lacks scientific guidance. } \\
\text { A2: Borche uses linear thinking to solve problems. }\end{array}$ & \multirow{3}{*}{$\begin{array}{l}\text { Spirit aspect: } \\
\text { (A1, B2) } \\
\text { Institution aspect } \\
\text { (B1, A2) } \\
\text { Behavior aspect: } \\
\text { (C1, C2) } \\
\text { Matter aspect: } \\
\text { (B3, C3) }\end{array}$} \\
\hline & $\begin{array}{l}\text { Textual evidence (B): } \\
\text { B1: The slogans of "digital Borche" and "happy } \\
\text { Borche" were put forward. } \\
\text { B2: We gradually summarize the core values of } \\
\text { Borche: security, integrity, responsibility, } \\
\text { excellence, and gratitude. } \\
\text { B3: We try our best to serve the customer and } \\
\text { devote ourselves to make products. }\end{array}$ & \\
\hline & $\begin{array}{l}\text { Verbal evidence }(\mathbf{C}) \text { : } \\
\mathrm{C} 1 \text { : In the early stage, Borche found no standard } \\
\text { theory to guide its production process. } \\
\mathrm{C} 2 \text { : When popularizing the Confucian culture, } \\
\text { some people may resist new things. } \\
\text { C3: The quality problems in the production of } \\
\text { products always exist. }\end{array}$ & \\
\hline
\end{tabular}

Source: field interview, August 2018.

Cultural Introduction Stage (2012-2014)

Since the introduction of Confucian culture, Borche has always been firmly confident in the power of mind, and believes that the power of mind is where the power comes from. At the spiritual level, Boche established the core values according to the "benevolence, righteousness, propriety, wisdom and faith" of Confucianism. At the institution level, Borche pursues the establishment of conscious order by advocating Wang Yang Ming's idea of "attaining liangzhi" (B3). In order to help employees understand and learn traditional culture, Borche held a series of cultural activities (A2) and take other actions to inherit and practice the traditional moral virtues (A1). At the matter level, Wang Yang Ming mentioned the importance of determination and held the idea that without determination, nothing can be fulfilled perfectly. As for Borche, the ambition is to innovate the injection molding machine. Borche upholds the integrity-based, customer-oriented principle and dedication to its customers to provide quality products and services (B2). Examples of evidence are shown in Table 6. 
Table 6. Evidence in Culture Introduction Stage

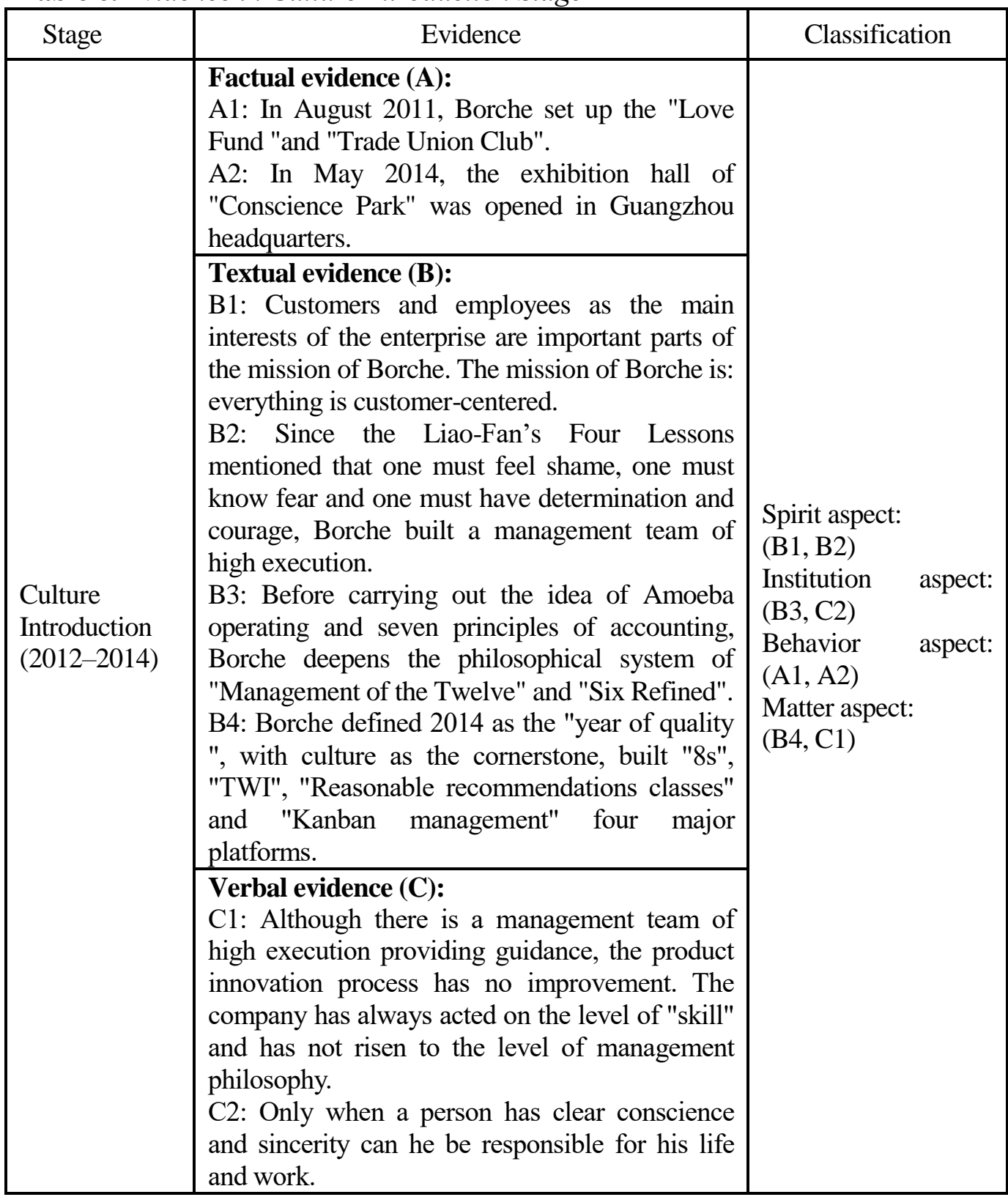

Source: field interview, August 2018

\section{Culture Development Stage (2015-now)}

After the above cultural evolution, Borcher has achieved its primary target of culture construction with continuous growth in business for several years. However, with the improvement of the Borche's management and business performance, there was overconfidence and opportunism within the company. In this regard, corporate culture was adjusted to deal with these new issues. Wang Shouren, a Confucian philosopher, once commented in his letter to friends that "the great trouble for our generations is that the scholars lied to each other with empty words. Only returning to simplicity is the right medicine".

In a cultural aspect, Borche chose to be honest and humble, empty himself 
and stick to its original values (A1). In terms of its management, Borche attempted to integrate various departments to build a one-experience system. In cultural construction, the enterprise managed to organize its training programs in a flat way where employees and management learning mutually. In its production, Borche stepped forward to intelligent manufacturing along with a new lean strategy. Examples of evidence are shown in Table 7.

Table 7. Evidence in Culture Development Stage

\begin{tabular}{|c|c|c|}
\hline Stage & Evidence & Classification \\
\hline \multirow{3}{*}{$\begin{array}{l}\text { Culture } \\
\text { Development } \\
\text { (2015-now) }\end{array}$} & $\begin{array}{l}\text { Factual evidence (A): } \\
\text { A1: The enterprise pays more attention to the } \\
\text { innovation ability of the personnel and gives the } \\
\text { talented person more development space to avoid } \\
\text { the phenomenon that bad money drives out good. } \\
\text { A2: Since September } 1,2017 \text {, Bo Chong has made } \\
\text { major changes in the governance structure of the } \\
\text { company, and invited Mr. Jiang Zixue, a well- } \\
\text { known lean management expert in China, to join } \\
\text { Borche as president. }\end{array}$ & \multirow{3}{*}{$\begin{array}{l}\text { Spirit aspect: (A1, } \\
\text { C1) } \\
\text { Institution aspect: } \\
\text { (B1, B2) } \\
\text { Behavior aspect: } \\
\text { (A2, C2) } \\
\text { Matter aspect: } \\
\text { (B3, B4) }\end{array}$} \\
\hline & $\begin{array}{l}\text { Textual evidence (B): } \\
\text { B1: After sales system changes, the enterprise } \\
\text { proposes a complete, systematic and advanced one- } \\
\text { stop intelligent solution for customers. } \\
\text { B2: The company proposes to integrate the supply } \\
\text { chain to promote the negotiation between } \\
\text { employees and suppliers, and then establishes an } \\
\text { effective supplier management system. } \\
\text { B3: As the first batch of } 46 \text { pilot demonstration } \\
\text { projects of intelligent manufacturing in China, } \\
\text { Borche put forward the concept of "injection } \\
\text { industry 4.0". } \\
\text { B4: In } 2017 \text {, Borche treats the two-board intelligent } \\
\text { injection molding machine as the company's } \\
\text { production focus. }\end{array}$ & \\
\hline & $\begin{array}{l}\text { Verbal evidence (C): } \\
\text { C1: In the beginning, everyone may be on the } \\
\text { condition of defensive, but this state of mind will } \\
\text { change gradually. } \\
\text { C2: We insist on writing a family letter every day } \\
\text { for five years. Now the whole company is studying } \\
\text { my letter, including my article - the letter from the } \\
\text { chairman. }\end{array}$ & \\
\hline
\end{tabular}

Source: field interview, August 2018.

From Tables 5-7, we come up with the last proposition:

Proposition IV: the corporate culture will be constantly adjusted with the change of the developmental stage. The internally cultural achievement will evolve to external influence. 
An enterprise should be seen as an open system where its culture is affected by internal and external pressures. But the determination is still the enterprise's original practice. For example, the initial cultural exploration and introduction heavily depend on the founders' ideas, styles and acts. The founders' personal influence will remain and form a corporate culture at the very beginning.

With the development of enterprises, the management is gradually influenced by the thought of leaders, and realizes that corporate culture construction is a way to build up an interpersonal relationship and improve employees' efficiency. In the process of cultural implementation, it gradually trickles down from the higher level to the general staff, and evolves into parallel learning under a series of measures such as comprehensive education. Employees' attitude will gradually accept and participate in the cultural construction, which are reflected in their daily work. These works constitute the company's system, products, sales and other strategies. In Table 8, we can clearly see the cultural evolution process in Borche.

Table 8. A Summary of Culture Construction Process

\begin{tabular}{|c|c|c|c|c|}
\hline Stage & Spirit aspect & $\begin{array}{c}\text { Institution } \\
\text { aspect }\end{array}$ & $\begin{array}{c}\text { Behavior } \\
\text { aspect }\end{array}$ & Matter aspect \\
\hline $\begin{array}{l}\text { culture exploration } \\
(2002-2011)\end{array}$ & $\begin{array}{c}\text { Corporate } \\
\text { culture is not } \\
\text { in } \\
\text { accordance } \\
\text { with the size } \\
\text { of the } \\
\text { enterprise. }\end{array}$ & $\begin{array}{l}\text { The production } \\
\text { system is not } \\
\text { scientific. }\end{array}$ & $\begin{array}{l}\text { Culture is not } \\
\text { fully } \\
\text { implemented } \\
\text { in Borche. }\end{array}$ & $\begin{array}{l}\text { Lack of } \\
\text { scientific } \\
\text { localization }\end{array}$ \\
\hline $\begin{array}{l}\text { culture introduction (2012- } \\
\text { 2014) }\end{array}$ & $\begin{array}{c}\text { Improve core } \\
\text { values in } \\
\text { Borche. }\end{array}$ & $\begin{array}{c}\text { The production } \\
\text { system is in } \\
\text { order. }\end{array}$ & $\begin{array}{l}\text { Culture } \\
\text { infiltration is } \\
\text { realized by the } \\
\text { employment of } \\
\text { top-down } \\
\text { processing. }\end{array}$ & $\begin{array}{c}\text { Lean } \\
\text { production } \\
\text { innovation }\end{array}$ \\
\hline $\begin{array}{l}\text { culture development } \\
\text { (2015-now) }\end{array}$ & $\begin{array}{l}\text { Stick to the } \\
\text { original } \\
\text { aspiration. }\end{array}$ & $\begin{array}{l}\text { The production } \\
\text { system uses the } \\
\text { one-stop } \\
\text { service } \\
\text { management. }\end{array}$ & $\begin{array}{l}\text { All workers } \\
\text { learn the } \\
\text { culture at the } \\
\text { same time. }\end{array}$ & $\begin{array}{c}\text { Intelligent } \\
\text { manufacturing }\end{array}$ \\
\hline
\end{tabular}

Source: Author 2019.

\section{Conclusion}

\section{Summary of the Cultural Internalization and Evolution Model}

Under the pressure of external competition and learned from its own practice, Borche has developed a Confucian culture mode that is suitable for long-term development. From the case of cultural construction, this paper draws the following two conclusions: First, local enterprises can introduce traditional norms and values into modern management when transforming their corporate culture. Confucian management thoughts are of a number of behavior norms from self-cultivation (gentleness, benevolence) to behavior (loyalty, trust) and interpersonal relationship 
(moderation, harmony) (Yum 1988, Hwang 2001) which can be applied to the management of enterprises. Second, the evolution of corporate culture needs to follow the life cycle of the enterprise's development. It is a common path to evolve from the internal spiritual level to the external level. The core of the cultural internalization is to reshape the values of employees and give full respect to their agency. The path is to stimulate the internal cultural identity of employees first, and then to strengthen the culture by external intervention. It is worth noting that in the final stage of mechanism, Borche chose to stimulate the employees' independent creativity and sense of mission by returning to the original point. This just reflects the highest level of management in a Confucian sense. The essence of Confucian thought of the supreme good is to give full play to the supreme good nature of human behavior through the common entity of enterprise organization, whose essence is to obtain the survival and happiness of the human community. On this basis, employees will work together to achieve the ultimate vision of the enterprise.

The research of this paper also has implications for the practice of enterprise management. Western management thought is mainly based on the hypothesis of "economic man", and the pursuit of efficiency is always the core principle of management theory (Gladwin et al. 1995, Leibenstein 1976, Pfouts et al. 1976). This theory emphasizes on improving efficiency and reducing costs through corporate regulation. Borche adopted western management thought at the beginning of its establishment, but due to the lack of corresponding incentive measures, this system could not function well as they expected. Confucian management thought plays a different role in education. Through inculcating filial piety, honesty, gratitude and other thoughts into employees, Borche cultivates its employees with high engagement. It is found that the degree of engagement is related to the characteristics of employees' sense of responsibility (Kim et al. 2009), achievement needs (Hallberg et al. 2007), and the work resources provided by enterprises such as organizational support and work characteristics (Saks 2006). Borche is a typical private manufacturing enterprise which has developed for more than ten years since it was born. During this period, it constantly introduces Confucian culture, self-adjustment and reflection, until it explores the corporate culture suitable for its long-term development. Therefore, other start-ups can also effectively change the values of employees and shape employees with high engagement by embedding Confucian management ideas in management.

\section{Research Limitations}

This paper is an exploratory case study aiming to identify the key elements. It comes up with a theoretical model from a business case. However, the external validity of our propositions and model in the research needs further examination. Next, in the collection of interview data, this study adopts the theoretical sampling method. Although theoretical sampling helps to develop theory, it may also ignore relevant information (Eisenhardt and 
Graebner, 2007). For example, most of the interviewees in this study are the chairman and senior managers of Borche. Without feedback from entry-level staff, this sample is not fully represented in our evaluation of cultural construction.

\section{References}

Cheng YH (2007) Core competencies and sustainable competitive advantage in air-cargo forwarding: evidence from Taiwan. Transportation Journal 46(3): 5-21.

Cheng Z (2014) Effective leadership of virtue: an analysis of political leadership from the perspective of Confucianism. Chinese Journal of Management 11(11): 1601-1604.

Conbere JP, Heorhiadi A (2006) Cultural influences and conflict in organizational change in new entrepreneurial organizations in Ukraine. International Journal of Conflict Management 17(3): 37-45.

Eisenhardt KM, Graebner ME (2007) Theory building from cases: opportunities and challenges. Academy of Management Journal 50(1): 25-32.

Ellinas C, Allan N, Johansson A (2017) Dynamics of organizational culture: individual beliefs vs. social conformity, PLoS One 12(6): 1-20.

Gladwin TN, Kennelly JJ, Krause TS (1995) Shifting paradigms for sustainable development: implications for management theory and research. Academy of Management Review 20(4): 874-907.

Hallberg UE, Johansson G, Schaufeli WB (2007) Type A behavior and work situation: associations with burnout and work engagement. Scandinavian Journal of Psychology 48(2): 135-142.

Hofstede G, Bond MH (1988) The Confucius connection: from cultural roots to economic growth. Organizational Dynamics 16(4): 5-21.

Hofstede G, Neuijen B, Ohayv DD, Sanders G (1990) Measuring organizational cultures: a qualitative and quantitative study across twenty cases. Administrative Science Quarterly 35(2): 286-316.

Hwang K (2001) The deep structure of Confucianism: a social psychological approach. Asian Philosophy 11(3): 179-204.

Ip PK (2009) Is Confucianism good for business ethics in China? Journal of Business Ethics 88(3): 463-476.

Kim HJ, Shin KH, Swanger N (2009) Burnout and engagement: a comparative analysis using the big five personality dimensions. International Journal of Hospitality Management 28(1): 96-104.

Leibenstein H (1976) Beyond economic man. Cambridge: Harvard University Press.

Liu GM (2006) Corporate culture. Beijing: Economic Management Press.

Nadkarni S, Barr PS (2008) Environmental context, managerial cognition and strategic action: an integrated view. Strategic Management Journal 29(13): 1395-1427.

Pfouts RW, Hirsch A, Hunt EK (1976) Rational economic man: a philosophical critique of neo-classical economics. Journal of Economic Issues 10(3): 640-650.

Sackmann S (1997) Cultural complexity in organizations: inherent contrasts and contradictions. London: Sage Publications.

Saks AM (2006) Antecedents and consequences of employee engagement. Journal of Managerial Psychology 21(7): 600-619.

Wang SJ (2015) Field research on enterprise culture evolution path and influence on its performance. Journal of Shanxi University of Finance and Economics 37(7): 71-84.

Xin R, Xu SY (2004) Corporation culture of state-owned enterprises: an inductive analysis of its dimension and influence. Beijing: Peking University Press. 
Vol. 7, No. $4 \quad$ Gu \& Liu: Crafting a Confucian Culture in Chinese Corporations...

Yin RK (2013) Case study research: design and methods. London: Sage Publications.

Yum JO (1988) The impact of Confucianism on interpersonal relationships and communication patterns in East Asia. Communication Monographs 55(4): 374-388. 